\title{
IDENTIFIKASI AKUIFER DANGKAL DI PULAU TERDEPAN NKRI DENGAN METODA GEOLISTRIK 2D: STUDI KASUS PULAU LAUT, KAB. NATUNA
}

\author{
IDENTIFICATION OF SHALLOW AQUIFER IN NKRI FRONTIER \\ ISLAND WITH 2D GEOELECTRICAL METHOD: CASE STUDY PULAU \\ LAUT, NATUNA REGENCY
}

\author{
Dino Gunawan Pryambodo*, Joko Pihantono, Reiner Arief Troa, Eko Triarso \\ Pusat Penelitian dan Pengembangan Sumberdaya Laut dan Pesisir \\ Balitbang Kelautan dan Perikanan, Kementerian Kelautan dan Perikanan \\ Gedung Balitbang KP Lantai 4, Jl. Pasir putih 1, Ancol Timur, Jakarta 14430 \\ *E-mail: dino@kkp.go.id
}

Naskah diterima: 15 April 2016, direvisi: 26 Mei 2016, disetujui: 30 Mei 2016

\begin{abstract}
ABSTRAK
Kebutuhan akan air bersih untuk menunjang aktivitas masyarakat di bidang perikanan di pulau terluar sangat diperlukan karena di lokasi tersebut kondisinya minim sumber air tawar. Penelitian geofisika dengan metode Geolistrik 2D telah dilakukan untuk mengidentifikasikan keberadaan akuifer di Pulau Laut, Kabupaten Natuna sebagai pulau terluar dari wilayah Negara Kesatuan Republik Indonesia (NKRI). Pengukuran di lapangan dengan enam lintasan geolistrik 2D menggunakan konfigurasi Wenner, bentangan kabel 160 meter, untuk mendapatkan kedalaman penetrasi 26,9 meter di bawah permukaan. Data tahanan jenis di Pulau Laut digunakan untuk mengidentifikasi keberadaan akuifer di daerah penelitian. Akuifer berada pada kedalaman yang bervariasi di dekat permukaan dengan kedalaman 2,5 - 13 m di jalur utara, jalur PDAM, dan jalur Air Paying; 12 - 26,9 m di jalur Kadur, jalur Air Bunga, dan jalur Air Paying. Nilai tahanan jenis untuk setiap akuifer bervariasi di setiap jalur. Nilainya berkisar antara $0,651-14 \Omega \mathrm{m}$. Litologi penyusun akuifer adalah satuan batupasir di jalur Kadur, Air Bunga, Talaga Tasik dan Air Paying; batulanau di jalur PDAM; dan batugamping di jalur utara.
\end{abstract}

Kata kunci: akuifer, metode geolistrik 2D, Pulau Laut, Natuna

\begin{abstract}
The need for fresh water to support community activities in the field of fisheries on the frontier island is necessary because this location has minimal condition to the source of fresh water. Geophysical research with $2 D$ geoelectrical methods conducted to identify the aquifers in the area of Pulau Laut, Natuna Regency as the frontier island of United Country of Republic Indonesia (NKRI). In field, measurement is using six $2 D$ geoelectric lines with Wenner configuration and $160 \mathrm{~m}$ cable stretching to obtain $26.9 \mathrm{~m}$ sub-surface depth penetration. Resistivity data in Pulau Laut used to identify the aquifer presence in research area. Aquifers are located on varies depth near the surface with a depth of 2.5-13 m in north line, PDAM line, and Air Paying line; $12-26.9 \mathrm{~m}$ in Kadur line, Air Bunga line, and Air Paying line. Resistivity value for each aquifer varies for each line. They are ranging from $0.651-14 \Omega \mathrm{m}$. Lithologies, composing the aquifer, are sandstone unit in Kadur, Air Bunga, Talaga Tasik, and Air Paying lines; silstone in PDAM line; and limestone in the north line.
\end{abstract}

Keywords: aquifer, 2D geoelectrical method, Pulau Laut, Natuna 


\section{PENDAHULUAN}

Keberadaan pulau-pulau terluar memiliki posisi strategis sebagai Kawasan Strategis Nasional Tertentu (KSTN) yang memiliki sumber daya alam dan jasa lingkungan yang tinggi dan peran strategis dalam menjaga kedaulatan Negara Kesatuan Republik Indonesia (NKRI) [1]. Namun, ada beberapa kendala dalam pengembangan pulau-pulau terluar, terutama ketersediaan sumber daya air tawar sebagai air baku untuk kehidupan sehari-hari. Upaya penyediaan air baku untuk masyarakat pulau-pulau terluar perlu dikaji sehingga dapat memberikan informasi keberadaan air tawar mengingat karakterisasi hidrologi sumber daya air tawar di pulaupulau terluar memiliki perbedaan tersendiri jika dibandingkan dengan karakterisasi hidrologi di wilayah daratan.

Sumber daya air di pulau-pulau kecil/pulau terluar bisa berupa air permukaan, airtanah, maupun air atmosferik (hujan). Air hujan adalah salah satu sumber utama masukan air tawar di wilayah pulau serta keberadaannya akan sangat tergantung dari musim yang sedang berlangsung. Geologi, morfologi, hujan, beserta faktor iklim lainnya merupakan faktor yang dominan mempengaruhi potensi airtanah dan bersama sama akan membentuk suatu sistem hidrologi pulau [2].

Secara geologi Pulau Laut terbentuk dari Formasi Bunguran. Satuan batuan yang termasuk formasi ini adalah batulanau termalihkan, tuf, dan rijang yang terdapat dalam bentuk perselingan. Batulanau berwarna putih kekuningan hingga kemerahan keras dan bersisipan dengan batupasir sangat halus. Tuf berwarna putih kelabu, pada beberapa tempat dijumpai tuf yang berwarna kemerahan, umumnya keras, mengandung radiolaria, dan berselingan dengan rijang. Rijang berwarna putih kelabu dan coklat kemerahan, sangat keras, di beberapa tempat dijumpai urat kuarsa, dan sisipan karbon. Karena terlipat kuat maka ketebalan sulit diukur. Kontak dengan batuan di bawahnya tidak teramati tetapi diperkirakan karena hubungan struktur sedangkan kontak dengan batuan di atasnya tidak selaras. Lingkungan pengendapan formasi ini adalah laut dalam [3].

Lokasi penelitian ini berada di Kecamatan Pulau Laut, Kabupaten Natuna dengan luas $37,59 \mathrm{~km}^{2}$ (Gambar 1) yang terdiri dari tiga desa, yaitu Desa Air Paying, Desa Tanjung Pala, dan Desa Kadur dengan jumlah penduduk berjumlah 2.400 jiwa [4].

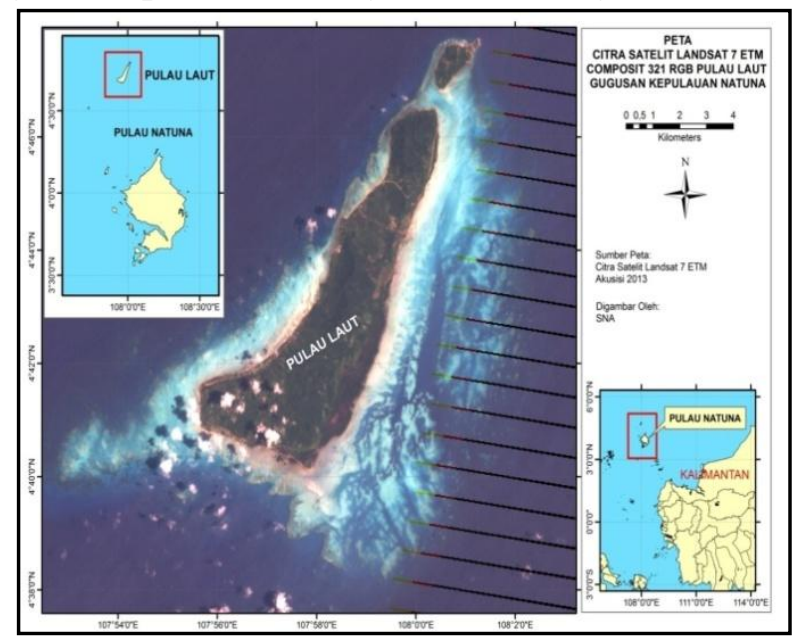

Gambar 1. Lokasi penelitian [5].

\section{METODOLOGI}

Airtanah merupakan air yang bergerak di dalam tanah yang terdapat di dalam ruang antar butir-butir tanah yang meresap ke dalam tanah dan bergabung membentuk lapisan tanah yang disebut akuifer [6]. Akuifer adalah suatu lapisan, formasi, atau kelompok formasi satuan geologi yang tidak kedap air (permeable), baik yang terkonsolidasi (misalnya lempung) maupun yang tidak terkonsolidasi (pasir) dengan kondisi jenuh air dan mempunyai suatu besaran konduktivitas hidraulika (K) sehingga dapat 
membawa air (atau air dapat diambil) dalam jumlah (kuantitas) yang ekonomis [7]. Berdasarkan sifat fisik dan kedudukannya dalam kerak bumi terdapat akuifer dangkal dan akuifer dalam. Akuifer dangkal atau akuifer bebas, yaitu suatu akuifer tak tertekan (unconfined aquifer) disebut juga dengan airtanah dangkal dengan kedalaman umumnya $<20 \mathrm{~m}$ dari atas permukaan tanah [8]. Airtanah dangkal adalah airtanah yang paling umum dipergunakan sebagai sumber air bersih oleh penduduk di sekitarnya.

Metode geolistrik merupakan metode yang banyak sekali digunakan dan hasilnya cukup baik, yaitu untuk memperoleh gambaran mengenai lapisan tanah di bawah permukaan dan kemungkinan terdapatnya air tanah. Pendugaan geolistrik ini didasarkan pada kenyataan bahwa material yang berbeda akan mempunyai tahanan jenis yang berbeda pula apabila dialiri arus listrik [9]. Peningkatan konsentrasi ion pada fluida akan meningkatkan konduktifitas fluida dan menurunkan nilai tahanan jenis batuan secara keseluruhan [10]. Satuan tahanan jenis yang digunakan adalah Ohm meter. Beberapa penelitian terdahulu membuktikan bahwa pengaruh kandungan air akan menurunkan nilai tahanan jenis suatu batuan. Besar kecilnya penurunan nilai tahanan jenis tergantung pada kandungan air yang ada di dalam pori-pori (porositas) batuan [11]

Survei dilakukan dengan menggunakan alat survei GPS (Global Positioning System) Garmin tipe 78s (Gambar 2) untuk menentukan posisi lintasan dan resistivitymeter Multichannel $S$ Field (Gambar 3) untuk mengukur nilai beda potensial sesuai dengan konfigurasi elektrode yang digunakan. Peralatan lain yang digunakan dalam pengukuran mencakup elektrode potensial, elektrode arus, akumulator, kabel, dan perlengkapan pendukung seperti meteran, kalkulator, multitester, dan handy talky (HT).

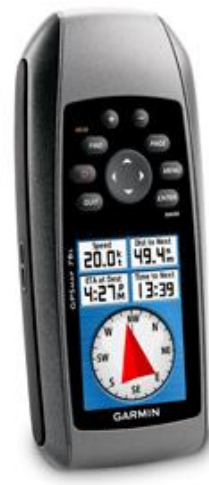

Gambar 2. Garmin 78s [12].

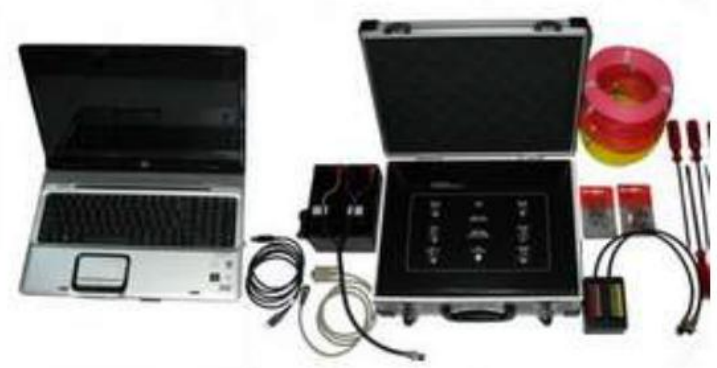

Gambar 3. Resistivitymeter Multichannel S Field [13].

Secara kasar bisa dikatakan bahwa metode $2 \mathrm{D}$ adalah penggabungan metode $1 \mathrm{D}$ dengan jumlah titik elektrode yang cukup banyak dalam suatu panjang tertentu (sesuai banyaknya elektrode dan panjang kabel yang tersedia). Semua konfigurasi simetris yang ada dalam cara geolistrik 1D dapat digunakan dalam metode 2D. Dalam survei lapangan digunakan konfigurasi Wenner karena resolusi yang cukup baik secara horisontal maupun vertikal dan kedalaman penetrasi yang cukup dalam. Keunggulan dari konfigurasi Wenner (Gambar 4) ini adalah ketelitian pembacaan tegangan pada elektrode MN lebih baik dengan angka yang relatif besar karena elektrode MN yang relatif dekat dengan elektrode $\mathrm{AB}$. 


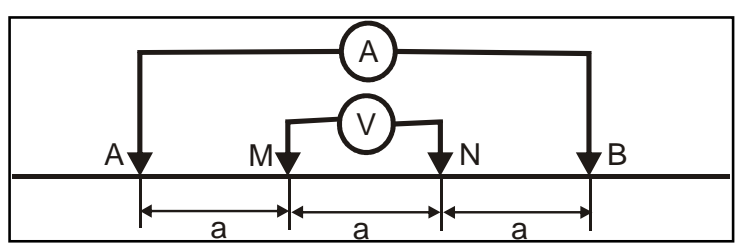

Gambar 4. Konfigurasi Wenner [14].

Di sini bisa digunakan alat ukur multimeter dengan impedansi yang relatif lebih kecil sehingga nilai resisitivitas semu didapat dengan persamaan di bawah ini [14]:

$$
\rho_{a}=K \frac{\Delta V}{I} \quad K=2 \pi a
$$

dimana :

$$
\begin{aligned}
& \rho \mathrm{a} \quad=\text { Tahanan jenis semu (ohm-m) } \\
& K=\text { Faktor Geometri } \\
& \Delta \mathrm{V} \quad=\text { Beda potensial }(\mathrm{mV}) \\
& \text { I } \quad=\text { Kuat arus yang dialirkan (milliAmpere) } \\
& \text { a }=\text { Jarak antara kedua elektrode arus (AB) } \\
& \text { dan elektrode potensial (MN) }
\end{aligned}
$$

Metode geolistrik 2D atau electrical imaging digunakan untuk melihat pola perubahan tahanan jenis batuan, baik secara vertikal maupun secara horizontal. Konfigurasi elektrode yang digunakan untuk pengukuran ini sama dengan pengambilan data geolistrik cara sounding atau 1D tetapi dengan teknik pengambilan data yang sedikit berbeda. Survei dilakukan pada lintasan yang lurus. Jumlah elektrode adalah 16 dengan jarak antar elektrode adalah 10 meter sehingga panjang lintasan pengukuran adalah 160 meter. Kabel multielektrode terbagi dua bagian, yaitu elektrode nomor $1-8$ di bagian kiri lintasan sedangkan nomor $9-16$ di bagian kanan lintasan. Peralatan geolistrik Multichannel S Field ditempatkan di tengah lintasan. Ujung tengah dari bagian kiri dan kanan kabel multielektrode dihubungkan dengan switchbox yang berfungsi untuk mengatur nomor elektrode yang berperan sebagai pengalir arus (A, B) dan pengukur beda potensial $(\mathrm{M}, \mathrm{N})$.

Pengukuran dilakukan setahap demi setahap dimulai dari bagian kiri (nomor elektrode kecil) dan tiap lapisan kedalaman (n). Setelah semua data yang diambil diplot maka akan diperoleh kumpulan data yang menyerupai perahu terbalik (Gambar 5). Pada gambar tersebut, diilustrasikan konfigurasi dari peralatan, kabel, dan sebaran titik pengukuran terhadap lapisan kedalaman. Setelah semua data didapatkan maka dilakukan pengolahan data sehingga diperoleh penampang tahanan jenis dari lintasan yang diambil, baik secara vertikal maupun horizontal atau kedalaman. Contoh kasus adalah pada konfigurasi elektrode Wenner dengan jarak elektrode "a" maka langkah pertama yang dilakukan adalah mengukur array elektrode 1a tempat elektrode nomor 1, 2, 3, dan 4 digunakan untuk pengukuran. Konfigurasi ini bergerak sejauh 1a. Setelah pengambilan data untuk spasi 1a, langkah berikutnya adalah dengan spasi elektrode $2 \mathrm{a}$ dan menggunakan elektrode nomor 1, 3, 4, dan 7; pengukuran data terus dilakukan sampai elektrode terakhir.

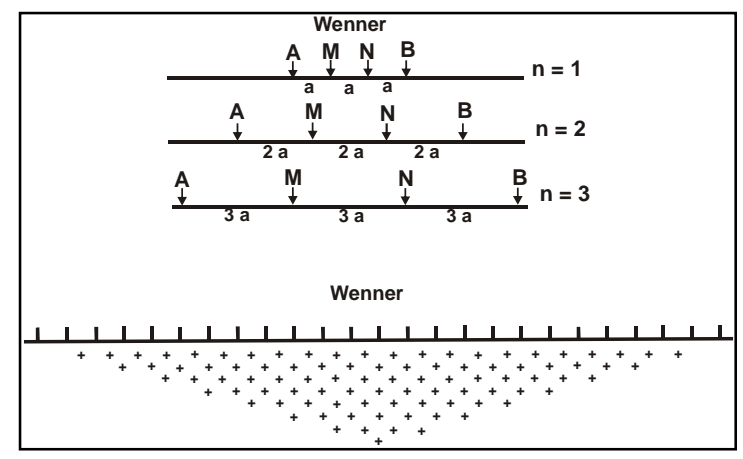

Gambar 5. Langkah pengambilan data geolistrik 2D konfigurasi Wenner [15].

Pengolahan data dilakukan dengan menghitung faktor geometri dari konfigurasi Wenner untuk menghilangkan pengaruh letak 
elektrode potensial terhadap letak kedua elektrode arus. Setelah diperoleh hasil faktor geometri dari konfigurasi Wenner kemudian menghitung tahanan jenis semu dan menginversi dengan program Res2Dinv [15] untuk memperoleh penampang 2D. Interpretasi data dilakukan dengan menggunakan pendekatan parameter nilainilai tahanan jenis material/benda dari penampang 2D hasil Res2Dinv.

\section{HASIL DAN PEMBAHASAN}

Hasil pengukuran geolistrik dengan metode Wenner 2D di lapangan diperoleh enam penampang tahanan jenis bawah permukaan di Pulau Laut (Gambar 6), yaitu lintasan Utara, lintasan Kadur, lintasan PDAM, lintasan Air Bunga, lintasan Telaga Tasik, dan lintasan Air Paying. Dari penampang tahanan jenis bawah permukaan dapat diinterpretasikan litologi bawah permukaan berdasarkan nilai tahanan jenis hasil pembacaan alat geolistrik.

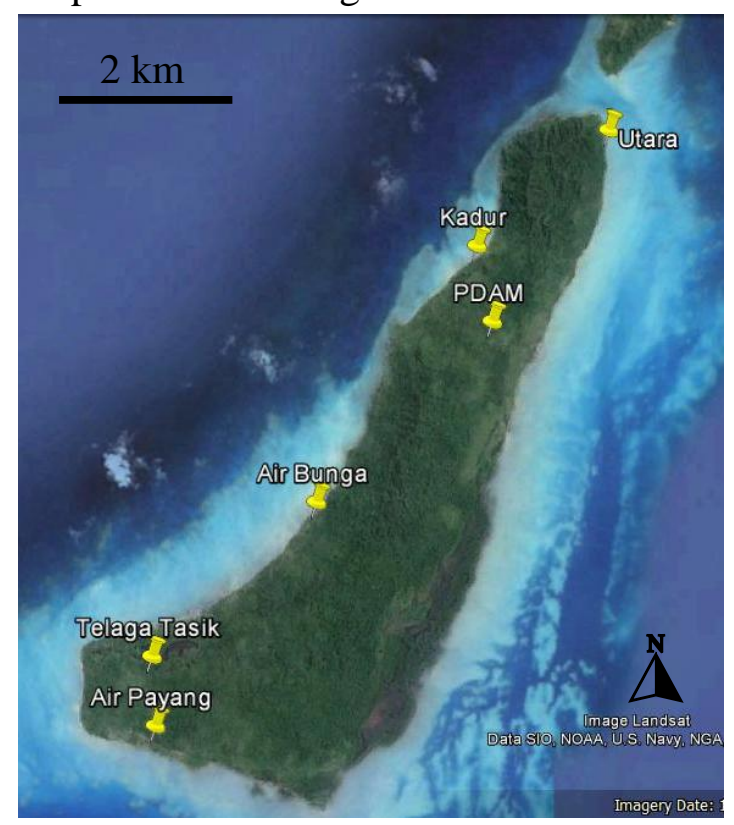

Gambar 6. Posisi lintasan geolistrik Wenner 2D.

\section{Lintasan Utara}

Lintasan Utara ini berada paling ujung utara dari Pulau Laut, dengan arah bentangan kabel utara - selatan. Pada lintasan ini kondisi lingkungannya berbukit dengan didominasi oleh batugamping yang tersingkap di permukaan. Panjang lintasan $160 \mathrm{~m}$ dan kedalaman penetrasi 29,9 meter di bawah permukaan tanah. Hasil dari pengolahan geolistrik Wenner 2D didapat suatu hasil penampang bawah permukaan (Gambar 7) yang dapat mengidentifikasi keberadaan akuifer air tanah. Pada penampang lintasan Utara ini diidentifikasi ada dua buah akuifer. Akuifer pertama terdapat pada jarak 40 - 50 meter dari arah utara dengan kedalaman akuifer antara 2,5 - 8 meter di bawah permukaan tanah dan akuifer kedua berada pada jarak antar 90 - 100 meter dari arah utara dengan kedalaman antara 3 - 20 meter dari permukaan tanah dengan nilai tahanan jenis untuk akuifer berkisar antara 1,92 - 5,27 $\Omega \mathrm{m}[16]$.

Terdapat dua litologi batuan pada lintasan Utara dari hasil intrepretasi dari penampang geolistrik, yaitu batugamping dan baturijang (Gambar 8). Keberadaan akuifer pada lintasan utara ini berada pada litologi batugamping. Akuifer ini terbentuk karena adanya rekahan di batugamping tersebut (Gambar 9). 


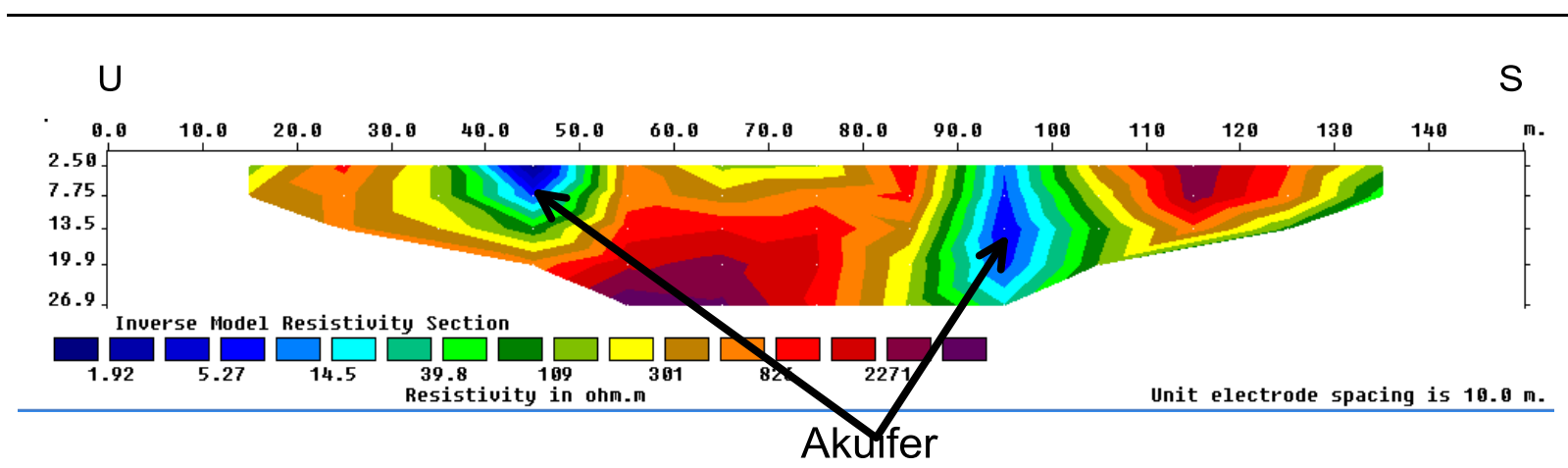

Gambar 7. Penampang geolistrik di lintasan Utara.

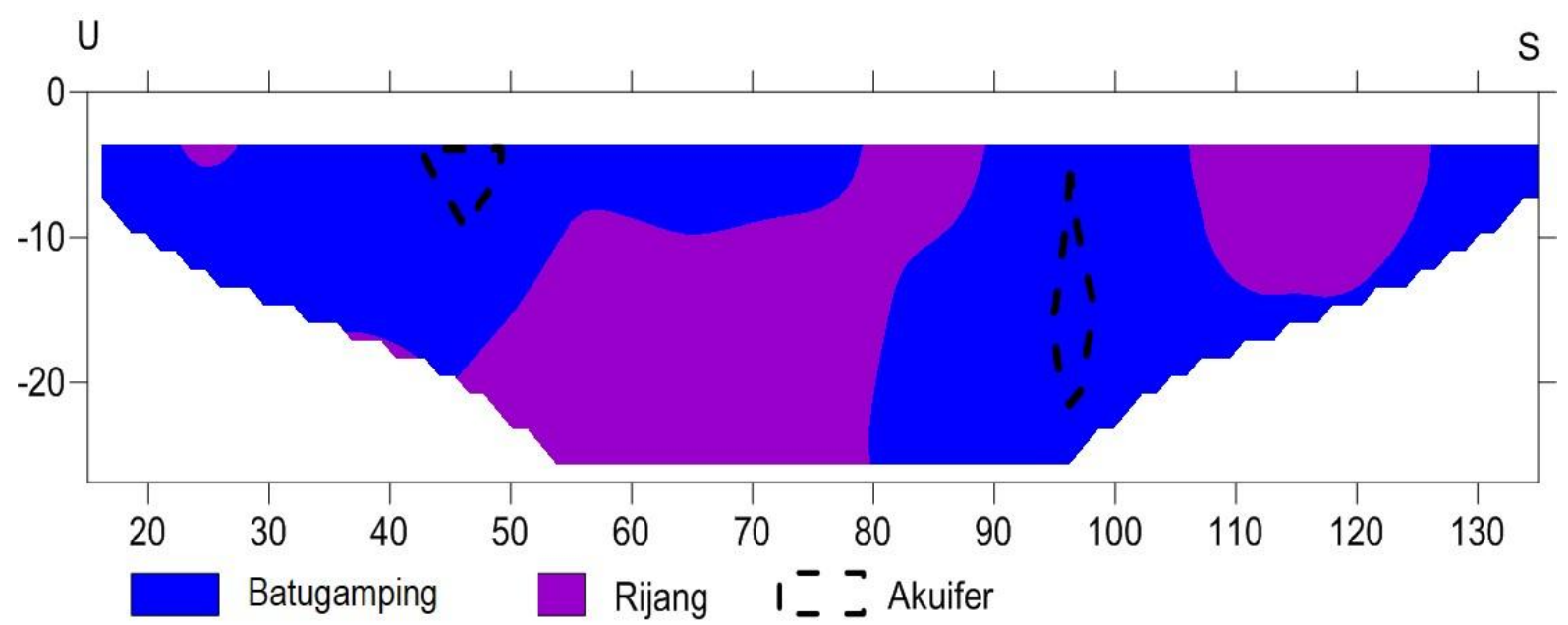

Gambar 8. Penampang litologi di lintasan Utara.

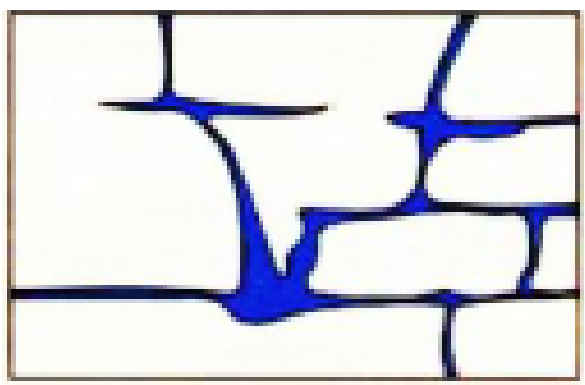

Gambar 9. Media akuifer rekahan pada batugamping [17].

\section{Lintasan Kadur}

Lintasan Kadur berada di Desa Kadur, dengan arah bentangan kabel geolistrik barat daya - timur laut. Lintasan geolistrik di Desa Kadur ini berada di dataran landai yang tidak jauh dari garis pantai. Panjang lintasan $160 \mathrm{~m}$ dan kedalaman penetrasi $29,9 \mathrm{~m}$ di bawah permukaan tanah. Hasil dari pengolahan geolistrik Wenner 2D didapat suatu hasil penampang bawah permukaan secara dua dimensi (Gambar 10) yang dapat mengidentifikasikan keberadaan akuifer airtanah. Pada penampang lintasan utara ini teridentifikasi akuifer pada jarak $90-100$ meter dari arah barat daya dengan kedalaman akuifer antara 12 - 26,9 meter di bawah permukaan tanah dengan nilai tahanan jenis antara $0,9-2,17 \Omega \mathrm{m}$.

Interpretasi litologi dari penampang geolistrik lintasan Kadur menghasilkan tiga satuan litologi di daerah tersebut yang berupa batugamping, tuf, dan batupasir (Gambar 11). Keberadaan akuifer pada lintasan Kadur ini berada pada litologi batupasir. Akuifer ini berada pada media berpori sehingga airtanah mengalir melalui rongga antarbutir yang terdapat dalam suatu batuan (Gambar 12). 


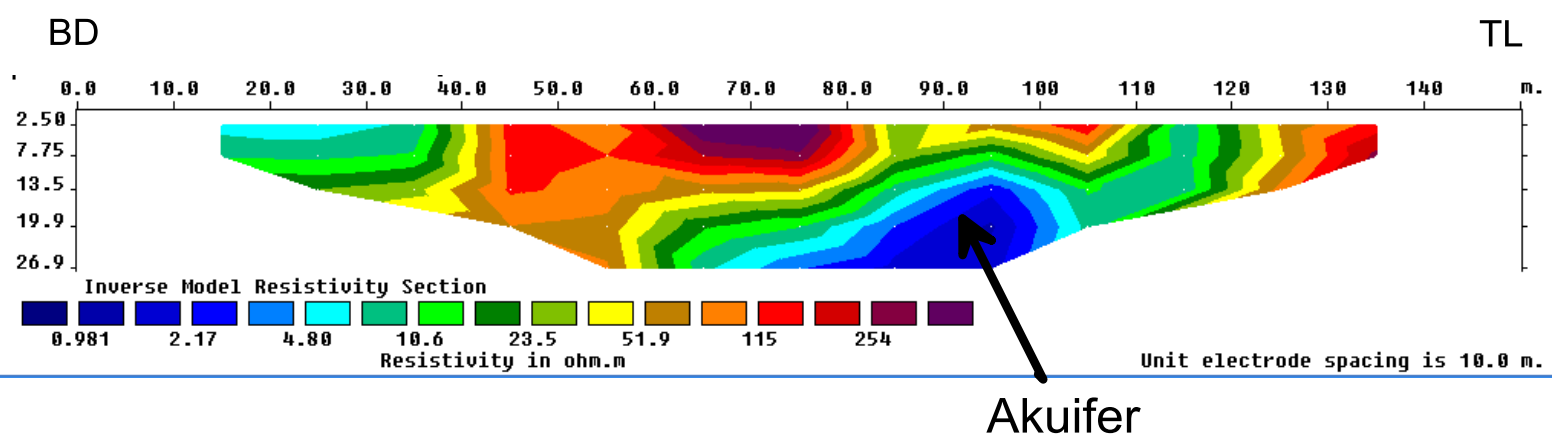

Gambar 10. Penampang geolistrik di lintasan Kadur.

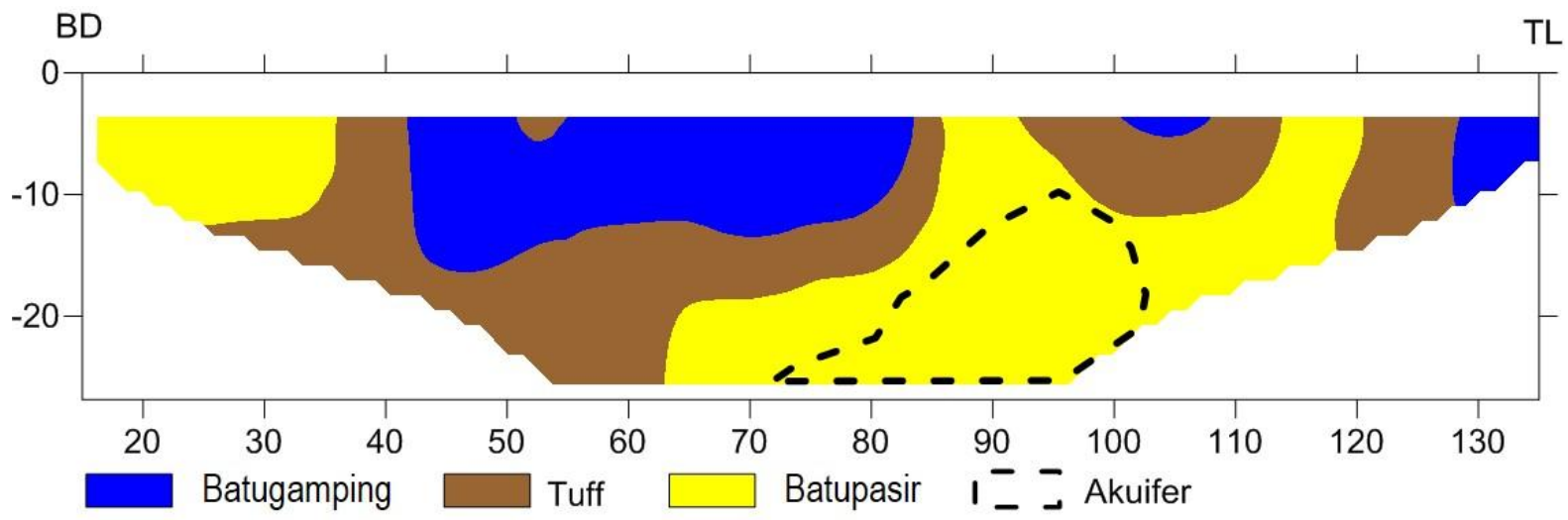

Gambar 11. Penampang litologi di lintasan Kadur.

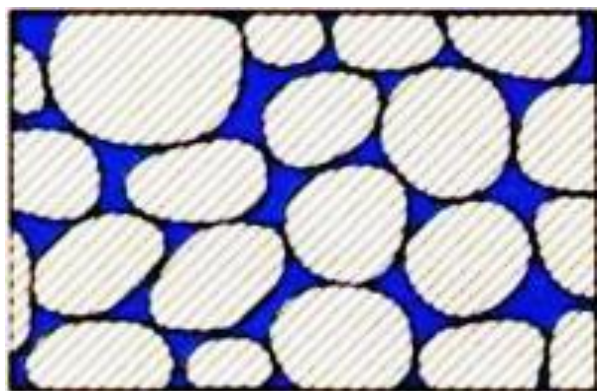

Gambar 12. Media akuifer berpori pada batupasir [17].

\section{Lintasan PDAM}

Lintasan geolistrik PDAM ini berada pada tengah Pulau Laut, dengan arah bentangan kabel geolistrik timur laut - barat daya. Lintasan geolistrik di daerah ini berada di dataran landai yang tidak jauh dari sumur gali. Panjang lintasan ini sejauh $160 \mathrm{~m}$ dan kedalaman yang didapat sedalam 29,9 meter di bawah permukaan tanah. Hasil dari pengolahan geolistrik Wenner 2D didapat suatu hasil penampang bawah permukaan secara dua dimensi (Gambar 13) yang dapat mengidentifikasikan keberadaan akuifer airtanah. Pada penampang lintasan utara ini diidentifikasikan akuifer terdapat pada jarak 60 - 70 meter dari arah timur laut dengan kedalaman akuifer antara 2,5 - 12 meter di bawah permukaan tanah dengan nilai tahanan jenis antara $3,10-9,43 \Omega \mathrm{m}$.

Hasil pengolahan data geolistrik 2D bawah permukaan di daerah ini lalu diinterpretasikan litologinya dari penampang geolistrik lintasan PDAM sehingga didapatkan dua satuan litologi di daerah tersebut yang berupa batugamping dan lanau (Gambar 14). Keberadaan air tanah pada lintasan PDAM ini berada pada litologi batulanau. 


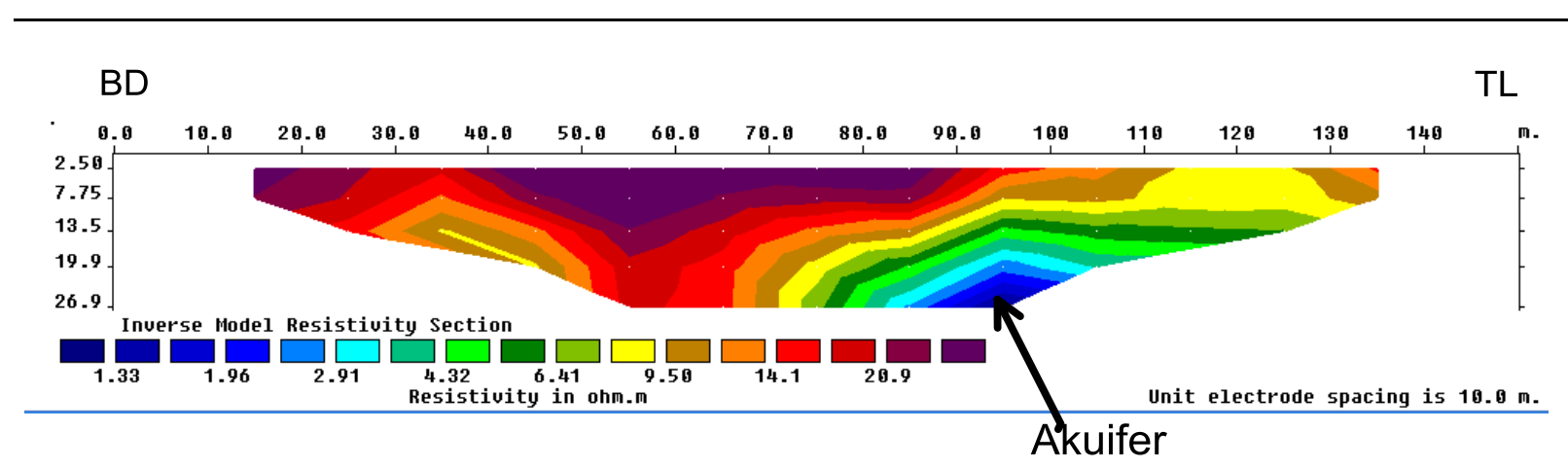

Gambar 15. Penampang geolistrik lintasan Air Bunga.

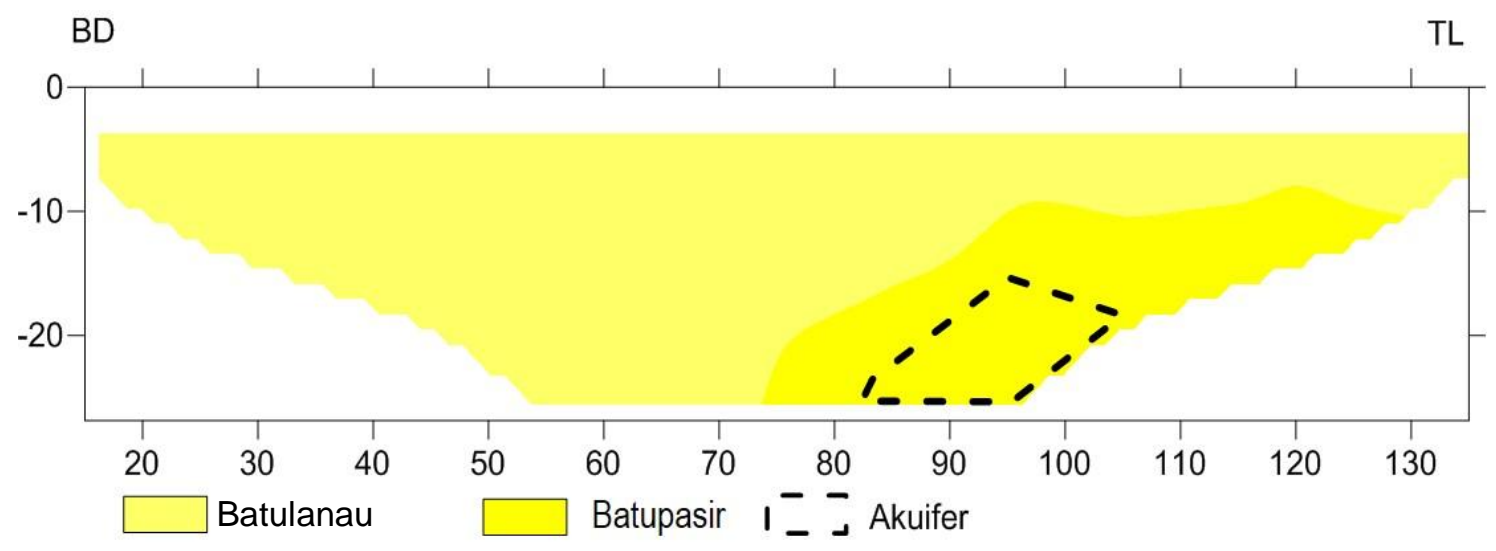

Gambar 16. Penampang litologi lintasan Air Bunga.

\section{Lintasan Telaga Tasik}

Lintasan Telaga Tasik merupakan lintasan yang berada pada telaga yang berfungsi sebagai sumber air bagi masyarakat di sekitarnya, dengan arah bentangan kabel geolistrik tenggara - barat laut. Lintasan geolistrik di Telaga Tasik berada di dataran landai. Panjang lintasan $160 \mathrm{~m}$ dan kedalaman penetrasi $29,9 \mathrm{~m}$ di bawah permukaan tanah. Hasil dari pengolahan geolistrik Wenner 2D didapat suatu hasil penampang bawah permukaan secara dua dimensi (Gambar 17) yang dapat mengidentifikasikan keberadaan akuifer airtanah. Pada penampang lintasan utara ini diidentifikasikan akuifer terdapat pada jarak 70 - 80 meter dari arah tenggara dengan kedalaman antara 2,5 - 13 meter di bawah permukaan tanah dengan nilai tahanan jenis antara 4,19- $14 \Omega \mathrm{m}$

Hasil pengolahan data geolistrik 2D bawah permukaan di daerah ini lalu diinterpretasikan litologinya dari penampang geolistrik lintasan Telaga Tasik sehingga didapatkan empat satuan litologi di daerah tersebut yang berupa batupasir, lanau, rijang, dan batugamping (Gambar 18). Keberadaan akuifer air tanah pada lintasan Telaga Tasik ini berada pada litologi batupasir. 


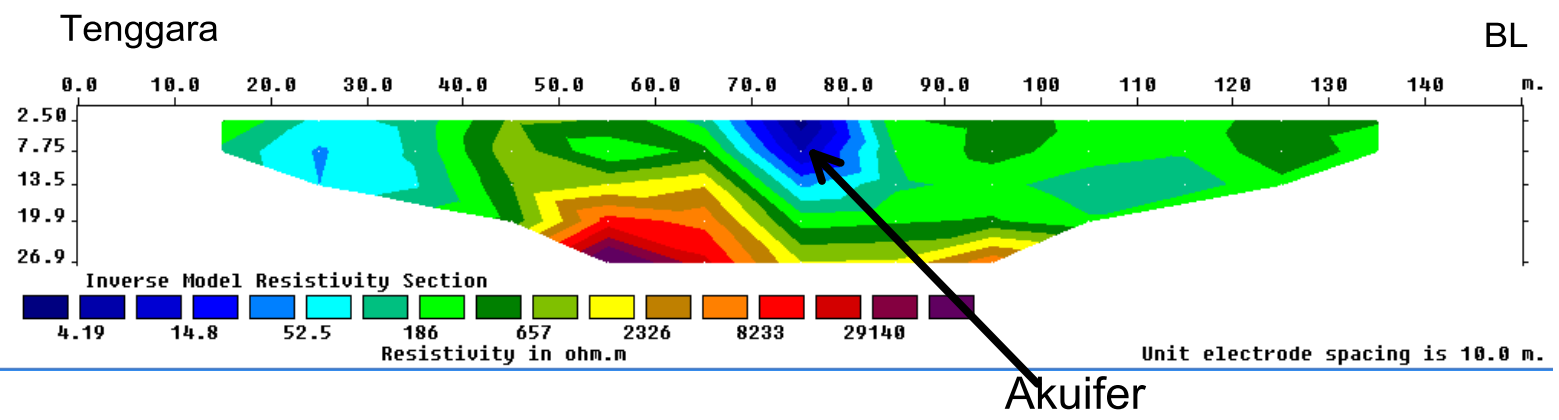

Gambar 17. Penampang geolistrik lintasan Telaga Tasik.

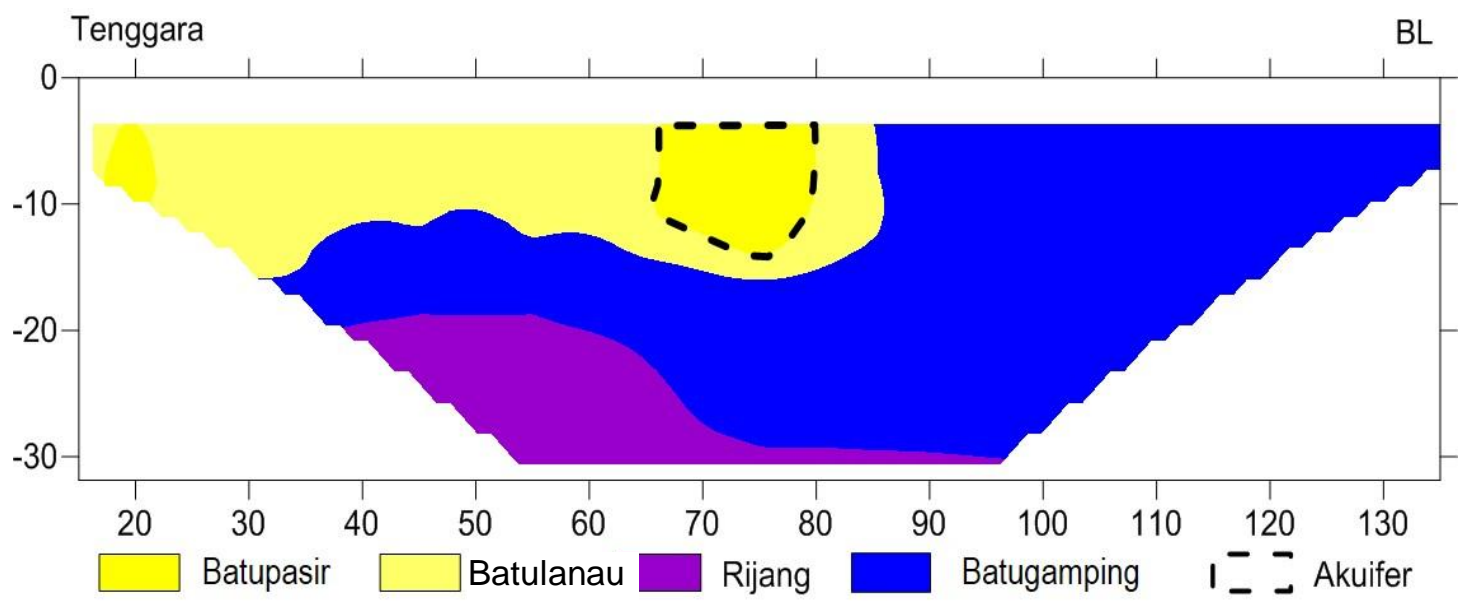

Gambar 18. Penampang litologi lintasan Telaga Tasik.

\section{Lintasan Air Paying}

Lintasan Air Paying terletak di Desa Air Paying yang merupakan pusat ibu kota dari Kecamatan Pulau Laut. Lintasan ini mempunyai arah bentangan kabel geolistrik barat - timur. Lintasan geolistrik di Desa Air Paying terletak pada dataran landai di depan kantor Kecamatan Pulau Laut. Panjang lintasan sejauh $160 \mathrm{~m}$ dan kedalaman penetrasi sedalam 29,9 $\mathrm{m}$ di bawah permukaan tanah. Hasil dari pengolahan geolistrik Wenner 2D didapat suatu hasil penampang bawah permukaan secara dua dimensi (Gambar 19) yang dapat mengidentifikasikan keberadaan akuifer air tanah. Pada penampang lintasan ini diidentifikasikan akuifer terdapat pada jarak 90 - $100 \mathrm{~m}$ dari arah barat dengan kedalaman akuifer antara $20-26,9 \mathrm{~m}$ di bawah permukaan tanah dengan nilai tahanan jenis antara $0,651-1,09 \Omega \mathrm{m}$.

Hasil pengolahan data geolistrik 2D bawah permukaan di daerah ini lalu diinterpretasikan litologinya dari penampang geolistrik lintasan Air Paying ini sehingga didapatkan tiga satuan litologi di daerah tersebut yang berupa batupasir, lanau, dan batugamping (Gambar 20). Keberadaan akuifer air tanah pada lintasan Air Paying ini berada pada litologi batupasir. 


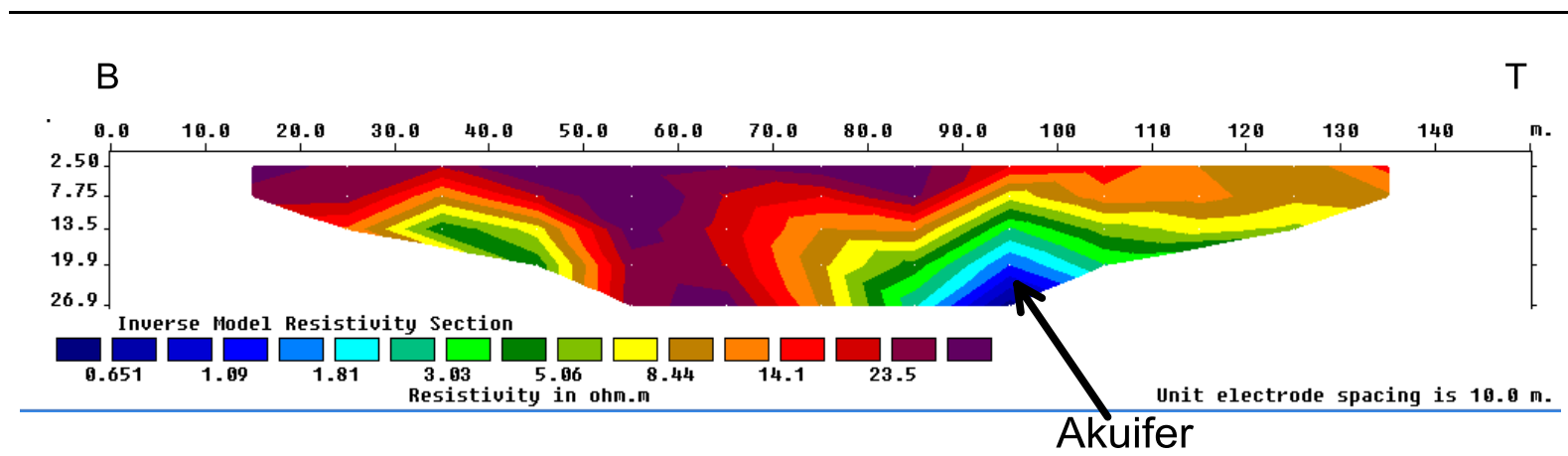

Gambar 19. Penampang geolistrik lintasan Air Paying.

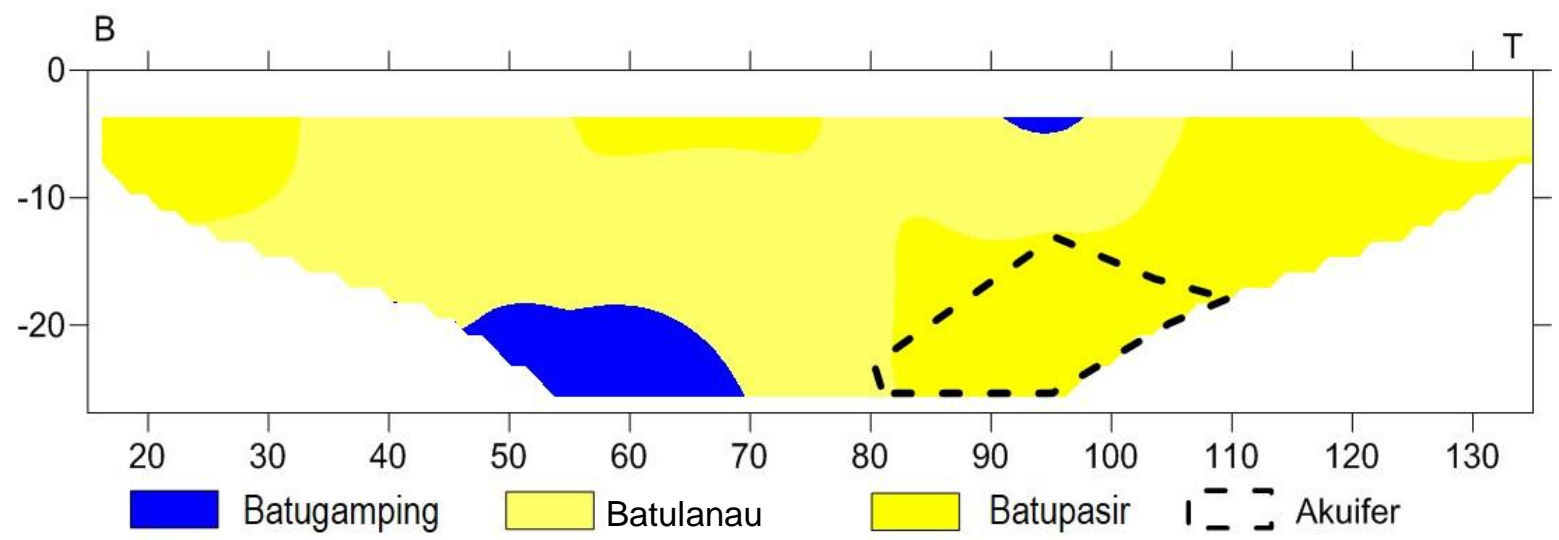

Gambar 20. Penampang litologi lintasan Air Paying.

\section{KESIMPULAN}

Dari hasil penelitian ini dapat disimpulkan antara lain: hasil interpretasi dari enam lintasan geolistrik 2D di Pulau Laut terdapat beberapa akuifer yang teridentifikasikan dengan kedalaman akuifer bervariasi. Akuifer yang dekat dengan permukaan dengan kedalaman 2,5 - $13 \mathrm{~m}$ antara lain lintasan Utara, lintasan PDAM, dan lintasan Telaga Tasik. Akuifer dengan kedalaman 12 - 26,9 m, yaitu lintasan Kadur, lintasan Air Bunga, dan lintasan Air Paying. Nilai resisitivitas untuk keberadaan akuifer dari tiap-tiap lintasan juga bervariasi yaitu antara $0,651-14 \Omega \mathrm{m}$.

Litologi penyusun akuifer terdiri dari beberapa satuan batuan antara lain satuan batupasir pada lintasan Kadur, lintasan Air Bunga, lintasan Telaga Tasik dan lintasan Air Paying; satuan batulanau pada lintasan
PDAM; dan satuan batugamping pada lintasan Utara.

\section{UCAPAN TERIMA KASIH}

Penulis mengucapkan terima kasih yang sebesar-besarnya kepada Keltibang Geodinamika dan Sumberdaya Laut dalam P3SDLP KKP yang telah membantu dalam pelaksanaan pengukuran geolistrik. Penelitian ini telah dibiayai dari dana APBN-P 2015 KKP tahun 2015.

\section{DAFTAR PUSTAKA}

[1] R. Indonesia, Peraturan Pemerintah Nomor 62 tentang Pemanfaatan Pulau-pulau Kecil Terluar. Indonesia, 2010.

[2] Delinom dan M. Robert, "Sumber Daya Air di Wilayah Pesisir dan Pulau-pulau Kecil," Jakarta, 2007.

[3] A. S. Hakim dan N. Suryono, Peta Geologi Lembar Teluk Butun dan Ranai, Sumatra. Bandung: Pusat Penelitian dan Pengembangan Geologi, 1994. 
[4] B. Kab.Natuna, "Statistik Daerah Kecamatan Pulau Laut," Natuna, 2015.

[5] USGS, "Citra Satelit Landsat 7 ETM," 2013. [Online].

Available: http://landsat.usgs.gov/landsat7.php. [Accessed: 04-Oct-2015].

[6] A. Herlambang, "Kualitas Air Tanah Dangkal di Kabupaten Bekasi,” IPB, 1996.

[7] R. J. Kodoatie, Pengantar Hidrogeologi. Yogyakarta: Andi Offset, 1996.

[8] G. P. Kruseman and N. A. De Ridder, Analysis and Evaluation of Pumping Test Data, 2nd ed. Wageningen: International Institute for Land Reclamation and Improvement, Wageningen, 1994.

[9] A. S. Wijaya, “Aplikasi Metode Geolistrik Resistivitas Konfigurasi Wenner untuk Menentukan Struktur Tanah di Halaman Belakang SCC ITS Surabaya," J. Fis. Indones., vol. 19 , no. 55, pp. 1-5, 2015.

[10] M. Hasanudin dan D. G. Pryambodo, "Studi Intrusi Air Laut di Cirebon dengan Menggunakan Metode Geolistrik," J. Segara, vol. 5, no. 2, pp. 121-133, 2009.
[11] D. Santoso, Pengantar Teknik Geofisika. Bandung: Departemen Teknik Geofisika ITB, 2002.

[12] GARMIN, “GPSMAP 78 Series Manual,” 2010. [Online]. Available: http://gpscentrs.lv/instrukcijas/GPSMAP_78_O M_EN.pdf. [Accessed: 06-Nov-2015].

[13] GEOCIS, "S Field Resistivity Automatic Multichannel (16 CH)," 2015. [Online]. Available: http://www.geocis.net/filedownload/S-FIELD-.pdf. [Accessed: 06-Nov2015].

[14] W. M. Telford, L. P. Geldart, and R. E. Sheriff, Applied Geophysics, 2nd ed. New York: Cambridge University Press, 1990.

[15] M. H. Loke, Tutorial 2D and 3D Electrical Imaging Surveys. Birmingham: Birmingham University, 2004.

[16] G. J. Palacky, "Resistivity Characteristics of Geologic Targets," in Electromagnetic Methods in Applied Geophysics Theory, Vol. 1, Okla: Society of Exploration Geophysicists, 1987.

[17] S. Mandel and Z. L. Shiftan, Groundwater Resources: Investigation and Development. London: Academic Press, 1981. 
Identifikasi Akuifer Dangkal di Pulau Terdepan NKRI

dengan Metoda Geolistrik 2D: Studi Kasus Pulau Laut, Kab. Natuna Oleh: Dino Gunawan Pryambodo, dkk. 